\title{
Sociopragmatic Elements and Possible Failure in EFL Teaching
}

\section{Nazli GÜNDÜZ*}

\section{Abstract}

Sociopragmatics conducts studies to understand the cross-cultural diversity among different nations, in terms of verbal and non-verbal elements. It studies different perceptions of the target culture in order to minimize intercultural factors hindering a learner's language proficiency to enable him/ her interpret culturally accepted folklore, gestures, sounds, and the use of space and time correctly. This paper aims at highlighting the importance of sociopragmatic elements such as idioms, proverbs, politeness norms, clichés, and the like, as well as as paralinguistics, kinesics, and proxemics in the learning and teaching of EFL. First, it summarizes the background of sociopragmatic studies, defines the concept, illustrates and exemplifies cross-cultural differences. Then, it focuses on the importance and proper usage of sociopragmatic elements in foreign language learning and teaching to acquire sociopragmatic competence and overcome failure. Further, it emphasizes that the language teacher should try to teach non-native students of English not only what is grammatically correct but also what is socio-pragmatically appropriate to prevent the occurrence of inter-cultural misunderstandings or communication breakdowns by presenting examples.

Key words: Sociopragmatics, EFL, Kinesics, Proxemics, Paralinguistics, Foreign Language Education. $\ddot{0} z$

\section{İngilizcenin Yabancı Dil Olarak Öğretiminde} Sosyopragmatik Öğeler ve Olası Hatalar

Sosyopragmatizm farklı milletlerdeki sözel ve sözel olmayan alanlardaki kültürlerarası çeşitliliğ anlamak için çalışmalar yürütür. Hedef kültüre farklı pencerelerden yaklaşarak, öğrencinin yabancı dil yeterliliğini engelleyen kültürlerarası faktörleri azaltmaya; folklor, jest, ses, mekan ve zamanla ilgili olan yapıların doğru kullanımın sağlamaya çalışırlar. Bu çalışma İngilizcénin yabancı dil olarak öğretiminde; deyim, atasözü, nezaket kuralları, sözcük kalıplarının yanı sıra paralinguistik, beden dili ve proksemik gibi sosyopragmatik unsurlarm önemini ortaya koyacaktır. Çalışma öncelikle sosyopragmatik çalışmayla ilgili bilgi verecek, kavramı açıklayıp, tasvir edecek ve kültürlerarası farkları örnekleyecektir. Sonrasında, yabancı dil öğrenimi ve ögrretiminde, sosyopragmatik yetkinlik kazanmak ve başarısızlı̆̆ gidermek için sosyopragmatik unsurlarm önemine ve uygun kullanımına odaklanacaktır. Böylece, öğretmenin Ingilizce ögrretirken sadece dilbilgisini değil, ayn zamanda sosyopragmatik olarak doğru olan kalıpları öğretmesinin önemi vurgulanacaktır. $B u$ da kültürlerarası yanlıs anlamaları ve iletişim hatalarının engellenmesini sağlayacaktır.

Anahtar kelimeler: Sosyopragmatizm, Ingilizcenin Yabancı Dil Olarak Öğretimi, Beden Dili, Kinezik, Dilötesi Ögeler.

* $\quad$ Yrd. Doç. Dr., Gazi Üniversitesi Edebiyat Fakültesi Batı Dilleri ve Edebiyatları Bölümü İngiliz Dili ve Edebiyatı Anabilim Dall. 


\section{Introduction}

Language being an important social tool for communication is used by human beings for ages in order to express feelings, desires, thoughts and wishes. The major aim of learning a foreign language $(\mathrm{FL})$ is to gain the ability to communicate with native speakers of the target language and express feelings, or convey thoughts to them accurately.

To communicate fluently, a FL learner is to acquire not only grammar, but also vocabulary, pronunciation, syntax, as well as cultural information. Social interaction is crucial in teaching, and daily talk is mostly culturally based. Since the 1960's the integration of language, culture and curriculum has been an objective in foreign language teaching (Kramsch 1994, 1). Politzer points the following:

As language teachers we must be interested in the study of culture not because we necessarily want to teach the culture of the other country but because we have to teach it. If we teach language without teaching the culture in which it operates, we are teaching meaningless symbols or symbols to which the students attach the wrong meaning; for unless he is warned, unless he receives cultural instruction, he will associate his concepts or objects with the foreign symbols $(1959,99)$.

"The study of utterances and their meanings in situations" is a field in linguistics which is called pragmatics (Leech, 1983: $\mathrm{x}$ ). On the other hand, the study which deals with language utterances within the context of language teaching where utterances are dealt with scrutiny is applied pragmatics. The latter places emphasis on real language usage, and when applied to teaching it focusses mainly on the component of sociopragmatics.

Sociopragmatics conducts studies to understand the cross-cultural diversity among different nations, in terms of verbal elements of language, such as lexical elements, syntactic elements, as well as non-verbal elements like paralinguistics, kinesics, and proxemics. In other words, it studies different perceptions of the target culture in order to minimize intercultural factors hindering a learner's language proficiency to enable him/her interpret culturally accepted folklore, gestures, sounds, and the use of space and time correctly.

This paper focuses on, and provides sociopragmatic elements and failure in English caused by cultural differences. First, a short introduction and background information on sociopragmatics, discourse rules and cross-cultural factors will be presented. Then, sociopragmatic elements such as idioms, proverbs, folklore, etc., playing a significant role in learning English as a foreign language (EFL) will be described in detail. Further, additional elements leading to failure in learning EFL'in Turkish context will be exemplified. 


\section{The Function of Sociopragmatics in Elt}

Socio-pragmatics which is a sub-branch of pragmatics is concerned with culture-specific studies. It uncovers the culture-specific background of language learning involving social or sociolinguistic dimensions, like the use of the rules of speaking. Sociopragmatic skills of foreign language learners exhibit both the linguistic competence and the communicative competence (Smith 1987, 11-20). These studies may investigate the variable use of pragmatic principles, and sociopragmatic elements, such as traditions, idioms, proverbs, and sociopragmatic elements.

Different individuals from different linguistic and cultural backgrounds may get faced to miscommunication, since pragmatic principles and rules differ from culture to culture. In one culture, for instance, it may be quite preferable to remain silent in a situation in which the norm of another culture requires sociable talk. Crystal reports that, at a dinner in an Arabic country, he made the mistake of remarking on the excellence of the food served for him, for he did not know that in Arabic culture it meant just the opposite. After the remark the host felt humiliated and apologized for the bad quality of the food, and then arranged some other meal for him $(1987,120)$.

Another example about cross-cultural differences again introduced by Crystal $(1987,20)$ is the principle of politeness expressions which vary in frequency and meaning in different cultures. Crystal informs us that many European languages do not use their words for thank you and please as frequently as English does. For example, in Finnish there is no equivalent word for please and if a request is done politely, it can be formulated with more polite forms, such as the Finnish equivalents of would you (visitko), or adding thank you (kiitos) or it's OK (ole hyvä) to the end of the sentence. In Turkish, the usage of the politeness marker changes according to the social level of the person. People belonging to lower status are direct and do not use the term please, as often as people belonging to higher level of status do. Request for a napkin from a waiter in English would respond as in Table 1.

\section{Table 1 : Request types for asking a napkin.}

\begin{tabular}{|c|c|}
\hline English Native Speaker Response(s): & $\begin{array}{l}\text { Sample equivalent Turkish responses ranging } \\
\text { from less formal to formal: }\end{array}$ \\
\hline Can I get a napkin, please? & Can you give me a napkin? \\
\hline Excuse me. Could I have a napkin, please? & Could you give me a napkin? \\
\hline Would it be possible to get a napkin? & Excuse me, could you bring a napkin? \\
\hline Would it be possible to get a napkin, please? & Could you bring me a napkin, please? \\
\hline
\end{tabular}


As seen above, Turkish requests are generally formed with the second person pronoun whereas English ones are formed with first person pronoun. This difference is caused by mother tongue interference, because students are applying their own norms to sentences with requests. Therefore these sociolinguistic differences have to be taught to students to have them realize and learn proper choice of vocabulary to achieve proper sociopragmatic competence.

Then, the function and force of the English thank you may also change when responding the following interrogative in different languages: Would you like some cake? In English speaking context thank you would mean yes, whereas the French merci and Turkish teşekkür ederim would mean no. When a person from one type of culture and a person from another type of culture encounter such situations, inevitably misunderstanding is likely to arise if both behave in accordance with their native norms. Moreover, though foreign language learners have excellent grammatical and lexical knowledge in the target language, they may still fail achieving successful communication because of lack of pragmatic competence. In order to overcome such miscommunications, the study of sociopragmatics should be applied to second/foreign language classes to teach the learners the cultural differences between the two languages.

\subsection{Discourse Rules and Failure}

A single sentence cannot be understood completely without considering its context because we string a number of sentences to each other. The rules in the ways which native speakers of a language hold conversations are named as discourse rules. We produce and comprehend sentences in terms of these rules, which can be telephone conversations, apologies, compliments or ironies that are culture specific. Without knowing such rules, we might cause ambiguity in our conversations with the native speakers of the target language. To illustrate, the statement: I like your hair may have different meanings and intentions according to its surface structure in the pragmatic context of discourse, in conjunction with its prosodic features of stress intonation, and its non-verbal features like gestures, eye contact, mimics and body language. The response to be given to the aforementioned sentence may therefore change as the major factor here is culture. According to Ellis (1986, 43) if the sentence is uttered as a compliment, in the United States it calls for a response. Not providing one is considered a failure in pragmatic competence. Second or foreign language learners may fail to respond to it appropriately, as well. They may ignore, give bare responses, or make negative transfer from their native language, which can be explained as a sociopragmatic error. 
Another sociopragmatic failure may occur in regard to telephone conversation expressions; in English telephone numbers are said one by one at the beginning of the conversation, in order to check whether one has dialed the right number. If this is not taught to students explicitly they may start the conversation according to the norms of their own culture, and either say the numbers in twos, or skip them, as in the following examples:

- Is that twenty-six, seventy-five, nine hundred ninety- nine...

- Hello. Is John at home?...

- Hello. I want to speak to John, please....

- Hello, I call for John ..........

Therefore, it would be better to introduce students with accurate telephone conversation expressions in dialogues from authentic resources like movies, audio recordings and provide them with drilling activities with telephone conversations. The following correct examples are introduced by Soars and Soars $(1995,109)$ :

- Is that two-six, seven, five, double oh?...

- This is John ...

- Could l speak to Ann, please?...

- Is Ann in?...

Additionally, when we consider the following telephone conversation, we can talk of sociopragmatic mother tongue interference. Here, speaker B incorrectly introduces herself as, I am+first name (FN) which resembles the discourse rules of Turkish conversation:
A: Hi, this is Mr. Brown.
B: Hello, Mr. Brown. I am Hale.

As seen in the examples above, each nation has its own rules of etiquette, and therefore learners have to be taught the correct manner of telephone conversations belonging to the target culture of the language they want to learn. So, it is recommended to the teacher of EFL to design varying activities for the classroom according to the norms of the target culture. 


\subsection{Sociopragmatic Transfer}

When speaking or writing in a second-language or when interacting with members of the target language, learners may use the rules of speaking from their native speech community, which is called sociopragmatic transfer as exemplified in the telephone conversation above. This phenomenon is variously referred to as interference or transfer from the native language (Wolfson 1989, 141). Positive and negative transfer is defined as the influence resulting from similarities and differences between the mother tongue and the target language.

Errors caused by negative transfer are more difficult to correct and overcome by learners, since it requires making changes in their own beliefs and values, in other words, their world view. Therefore, it is recommended to practice the sociopragmatic elements of the target culture frequently in the classroom because it fills the gap where grammatical rules fail to explain the language use.

\section{The Elements of Sociopragmatics}

Sociopragmatics is a culture-specific science that studies the cultural elements of communities; for, intercultural factors hinder learner's language proficiency due to cultural differences between the native and target language. Those elements which are covertly expressed throughout linguistic knowledge and communication can be divided into two parts (1) linguistic elements engraved in the grammar, such as lexical and syntactic elements (verbal elements); (2) non-grammatical elements, such as kinesics and proxemics (non-verbal elements).

\subsection{Lexical Elements}

Languages have strong cultural variations in terms of lexical items. Cultural values remain alive in folklore; that is, in idioms, proverbs, clichés and slang which are frequently used in daily speech. In the following section, verbal elements such as idioms, proverbs, slang, clichés, superstitions and traditions leading to sociopragmatic failure in English for Turks will be focused on in detail by providing examples.

\subsection{Verbal Elements Causing Failure in English}

Grammatical (verbal) elements have great impact on studying learner's errors stemming from different cultural backgrounds. Therefore, these types of elements comprise the main sources of lexical cultural differences in cross-cultural studies. In terms of syntactic cultural differences one has to focus on the structural system of the target language, since grammar oriented failure stems from the differences between the structures of the native and target language. 


\subsubsection{Idioms}

One of the main verbal elements of sociopragmatics is idioms which are taught to SL/ FL learners to have a potential influence on reflecting the cultural values of a community, for instance the English community. In the Longman idioms dictionary, Stern (1998, vii) defines an idiom as "a sequence of words which adds a different meaning to the group of words from the meaning each word would have separately". He further states that "idioms add color to English, helping the user emphasize meaning and make explanations lively and interesting”. Moreover, they communicate meaning in just a few words. If the idiom is present in the mother tongue of the learner, it will be easier for the learner to comprehend its meaning in the target language. In some cases some idioms are totally different from one's native language.

The following 10 idioms were chosen as the most ambiguous ones among 20 idioms presented in a freshmen class at Hacettepe University, ELT department. These seemed to cause sociopragmatic failure to Turkish students learning EFL, since the emphasized terms or phrases were not culturally familiar or mean just the opposite to students. It is sociopragmatics which provides the knowledge on how to use language output in speech acts according to different situations and social settings.

1. An albatross around somebody's neck.

The new school rules may prove to be an albatross for the students.

2. Get the bullet.

We were waiting around all week, wondering how many of us would get the bullet.

3. You big girl's blouse.

Go on then, try and hit me, you big girl's blouse.

4. Have eggs on one's face.

John was completely wrong about the weather. Now, he has eggs on his face.

5. Keep someone in stitches.

The comedian kept us in stitches for nearly an hour.

6. Woolgathering.

Sally never listens to the teacher. She is always woolgathering.

7. To twist someone's arm.

Jake: Pretty girls? Oh all right, you've twisted my arm, I'll come!

8. To go cold turkey.

A few months ago, my dad just announced one day he's quitting drinking. He just quit cold Turkey!

9. Rule of thumb.

As a rule of thumb you should always pay for your date's dinner. 
10. To be on the ball.

Your homework is not due until next week and you have already finished it, you're really on the ball. I wish I could be more organized.

(Stern, 1998; Curry, 1986; Dunkling, 1993)

Leech (1983) emphasizes that linguistic and lexical knowledge is not enough to be competent in using a FL. Both pragmatic and sociopragmatic competence is required to decide which vocabulary and phrases to use in a certain context. These competencies enable the learner use strategies relevant to the social situations they are in, and thus use appropriate language according to the social variables.

\subsubsection{Proverbs}

Other verbal elements of sociopragmatics are proverbs. All cultures have commonly a large number of proverbs which are transmitted by generations of those cultures. When two communities share nearly the same cultural values, there will not be any failure in the communication process in terms of proverbs. For instance in Christian circles, the proverb no cross, no crown will make people recall the crucifixion of Christ. Since Christian people share the same religion, for them it will not cause any difficulty to understand that proverb. But, for cultures unfamiliar to Christian religion the mentioned proverb will not make any sense.

Additionally, some proverbs mean nearly the same in both, mother tongue and the target language; therefore, they may not lead to misunderstanding. For example, the English proverb Bad news travels fast has the same equivalence and meaning in Turkish Kara haber tez duyulur.

On the contrary, there are a lot of proverbs in English which are not familiar to Turkish learners; and therefore, may cause misunderstanding when being encountered with them. Here, sociopragmatic which handles the cultural aspects of societies will help the learner to tackle with the problem.

The following proverbs were voted as the most problematic English proverbs for Turkish students among 20 ones which were brought into and discussed in the classroom (adapted from online English Proverbs prepared by Gary Martin (2016);

1. Even Homer sometimes nods.

2. Every family has a skeleton in the cupboard.

3. Hide not your light under a bushel. 
4. Do not ride the high horse.

5. Do not take your harp to the party.

6. Many cooks spoil the broth.

7. No cross, no crown.

Since the above mentioned proverbs have culture specific words like Homer, harp, cross, and broth which are unfamiliar to Turkish students, it can be difficult to internalize and comprehend the implied meaning of the proverbs. Teachers of EFL have to be aware of sociopragmatic qualities of language that do not overlap, and design their teaching accordingly.

\subsubsection{Slang}

Slang is a form of speech that everyone can recognize but no one can define. It is a part of casual, informal style of language use, which has always been regarded as a low form of language. However, it is known that next to the standard dialect, people use a different dialect, a social dialect, which shows their membership to a particular social group: teenagers, adolescents or gang members. That is, people often use a language to signal their membership of a particular group. Social status, sex, age, ethnicity and the kinds of social networks people belong to turn out to be important dimensions of identity in many communities (Holmes, 1992: 133)

The following examples for teen slang are adopted from the Cassell Dictionary of Slang (Green, 1998):

1. Audi (I am out of here).

2. To be at the races

3. Banna (teen)

4. Bargain bucket

5. Cheap John

6. Lick thumbs

7. Rat and mouse

8. Short of sheet

9. Use the old bean

10. Be kicking it 
Slang is generally more culture specific and differing from age group to age group, hence it is more difficult to have them understood in a different context as well as culture. Since it is a low form of language, it is not recommended to teach it in the EFL classroom. However, native users of English use slang in their daily lives, which is a natural process, and when ESL/EFL learners hear this, they do not understand it. Therefore, sociopragmatic studies attract more attention to even the teaching of slang for the sake of avoiding failure in communication and adopt language teaching goals according to the needs of students.

\subsubsection{Cliché}

A cliché is defined as a short expression that is overused because it is considered to be both illuminating and funny to say (Anmer, 1992: v). However, they are regarded as tediously repetitious, unoriginal, and they prevent the speaker from having to make any mental effort. Below there are some clichés which might be problematic for Turkish students learning EFL.

1. Break a leg

2. Dead as a doornail

3. A dog's age

4. Ants in one's pants

5. All thumbs

6. Apple pie order

7. Fifth wheel

8. As useful as tits on a bull

Limited knowledge of the appropriate social and cultural norms and lack of knowledge how to distinguish speech strategies in cross-cultural communication can lead to language failure in language choice of learners. Hence, teaching the unwanted sociocultural factors, such as the usage of clichés would prevent sociopragmatic failure.

\subsection{Elements of Folklore}

Folklore is any of the beliefs, customs, and traditions that people pass on from generation to generation. Much folklore consists of folk stories, such as ballads, fairy tales, folk tales, legends, and myths. Folklore also includes arts and crafts, dances, games, nursery rhymes, idioms, proverbs, riddles, songs, superstitions, holiday and religious celebrations. It can be said that folklore is as old as humanity, for written records left by the earliest people include 
examples of folklore. Much folklore is passed orally from person to person since people in those old days were illiterate. Even today, many peoples in third world countries do not have a written language, but they have oral folk songs, legends, myths, and other kinds of folklore. Sometimes folklore is handed down by imitation. For centuries, children have learned nursery rhymes, riddles, and fairy tales by imitating parents, grandparents, or other youngsters (Microsoft Encarta, 2000).

All the above mentioned sociopragmatic elements of folklore play a significant role in teaching a foreign language for they have to be included in the teaching process of the target language to teach communication accurately. There is no doubt that languages and cultures vary in terms of sociopragmatic norms and behaviour patterns and due to these facts crosscultural failure occur in learning the target language. Hence, although these failures are difficult to correct, they can be detected and pointed out by the teacher and discussed in the classroom by the aid of appropriate methodologies and activities, to lead to positive transfer and enable learners to form sociopragmatic competence.

\subsubsection{Non-Verbal Elements Causing Failure in learning English}

Nonverbal communication is the process of sending and receiving messages without uttering words, either spoken or written. Nordquist (2016) states that the term nonverbal communication was introduced for the first time by psychiatrist Jurgen Ruesch, and author Weldon Kees in the book Nonverbal Communication: Notes on the Visual Perception of Human Relations in 1956. Teaching and learning the non-verbal elements of foreign a language like paralinguistics, kinesics, proxemics, superstitions, and the like might lead to misunderstanding for learners, because these types of elements considerably vary from one culture to another.

\subsubsection{Paralinguistics}

Paralinguistics, in other words vocalics, is the study of vocal and sometimes non-vocal signals. These behaviors known as vocal behaviors of people are associated with the tone of voice, accent, stress, speech rate, pitch, and rhythm (Matthews, 2007). They convey messages, regulate conversational behavior and help the hearer detect various emotional states. Some researchers also include certain non-vocal elements, such as facial expressions and hand gestures under the heading of paralinguistics. Moreover, we can understand a person's age, gender, and dialect by those paralinguistic behaviors conveyed through the quality of voice. Nonetheless, according to Matthews (2007) the boundaries of paralanguage are unavoidably imprecise. 
See the following dialogue example introduced by Holmes (1992, 133):

(Telephone rings)

-Pat: Hello

-Caller: Hello. Is Mark there?

-Pat: Yes, Just hold on a minute.

-Pat (to Mark): There is a rather well-educated young lady from Scotland on the phone for you.

The telephone conversation reveals that, when one answers the phone, one can often guess about various characteristics of the speaker. Pat was able to deduce quite a lot about Mark's caller, even though the caller had not said anything explicitly about herself. Consequently, the quality of voice forms is not only personal but also cultural phenomena which are crucial to focus on in the process of teaching a foreign language.

\subsubsection{Kinesics}

The term kinesics, body language, coined by the anthropologist Ray Birdwhistell (1970) is the study of non-verbal communication using the methods and concepts of American descriptive linguistics of the late 1940s. It contains facial expressions, eye-gaze, eye-contact, head movements, hand movements, gestures, etc. For instance, think of a man standing inside a closed glass phone booth and you cannot hear a word he says, but you can see his posture, gestures, and facial expressions. Even if you do not hear him you can understand him interpreting his body movements, that is his kinesics.

Every culture uses body language and kinesics in unique ways. In the specific interpretation of gestures, there is a huge diversity, both cross-culturally and cross-linguistically. All human beings do the same actions, but again the use of these movements varies from culture to culture. Therefore, an understanding of kinesics across cultures necessitates a close look at posture, facial expressions, as well as gestures in language teaching. Otherwise, it might cause cross-cultural miscommunication, for the same gestures might be interpreted in different ways in the native culture. To exemplify, in a newspaper article Cotton (2013) states;

On Inauguration Day 2005, President George W. Bush raised his fist, with the index and little finger extended, to give the time honored hook 'em horns gesture of the Texas Longhorn football team to the marching band of the University of Texas. Newspapers around the world expressed their astonishment at the use of 
such a gesture. Italians refer to it as "il cornuto", which means that one is being cuckolded (that is, that his wife is cheating on him!) It is considered a curse in some African countries, and is clearly an offensive gesture in many other parts of the world.

For Turks, the same gesture resembles the gesture of the Nationalist Movement Party. Additionally the joining of the thumb and the index finger, forming the sign of $\mathrm{OK}$, to indicate everything is fine in English and zero in French, might lead to insult for Turkish EFL learners, since it is used to refer to homosexuality in Turkish context. Further, touching the forefinger to the head indicates a crazy person for American people, whereas it might be misunderstood by Turkish students because it indicates the opposite, a clever person in Turkish culture.

To avoid cross-cultural miscommunication, the ESL/EFL learners must be taught the kinesics of the target culture during the educational process. It is recommended to teach gestures which incorporate different meanings in cultures in order to prevent losing face in the target culture.

\subsubsection{Proxemics}

Proxemics is the study of interpersonal distance or spacing which plays an important role in teaching culture; for, cultures also vary widely in acceptable distances for conversation. In each culture the amount of space varies depending upon the nature of social interaction. All cultures seem to distinguish four basic categories as indicated by Hall (1966), which are intimate distance, personal distance, social distance and public distance. The space between two people during a conversation reveals what type of relationship they have. Vargas $(1986,106)$ explains; in the American and other low-contact cultures, the social distance is approximately $2-3.5 \mathrm{~m}$ and personal distance is $45-120 \mathrm{~cm}$. On the other hand, for Turks the personal distance is less far, since Turks are high-contact culture, just like in other Mediterranean cultures and they feel the need to touch people to be regarded more friendly and sincere.

Furthermore, the idiom elbow room explains the attitude of American culture of personal distance. It does not only mean the required space between two people but also freedom in a particular place or situation to do what you want to do or need to do. This also is better taught to Turkish students because they easily would touch the shoulder of an American tourist in a public bus to pass the fare, which would be regarded as violating the rules of personal distance (Sinclair, 1994: 454).

The reason why an EFL teacher should pay attention to the above mentioned rules, the cultural factors to his/her students is to prevent socio- pragmatic failure in the target language and thus heal communication breakdown. 


\subsubsection{Superstitions}

Superstitions are inseparable parts of people's beliefs, which exist in all cultures of the world. The belief in magic ghosts, fairies and signs of bad or good luck is also common in some cultures (Encarta, 2000). For example, touching wood which is believed to keep bad luck away exists in both Turkish and English cultures. On the contrary, some other superstitions like itching of the head, elbow or back of the neck are definitely culture specific. In ancient times English people thought that their itches were signs by which they could foretell the future. English superstitions which are unknown in the Turkish culture might cause miscommunication between English and EFL speakers and therefore better taught during the educational process by providing them with reading materials about those cultures, as well as featured videos, films and documentaries explaining those superstitious beliefs.

\subsubsection{Traditions}

Traditions which are the beliefs, holidays and customs passed from generation to generation within a culture also contain cross-cultural differences; therefore, they are regarded as a part of sociopragmatic elements. They are generally related to religion, beliefs and life style. Turkish learners of English are sometimes encountered with some important religious days or national holidays in American and British culture like Halloween or Thanksgiving Day in textbooks. Sometimes they are misunderstanding the traditions of the English. For example, they are not familiar with Christianity and its related ceremonies, such as the decoration of a pine tree or hanging up stockings by the chimney, and try to imitate them without knowing the underlying reasons.

Those kinds of traditions which are cultural specific cause failure in learning the target language and culture properly; learners cannot find equivalence in meaning for those in their native language.

The difference and underlying meaning is better taught to students in the classroom, so that they will pay attention not to cause any misunderstanding when meeting people from the target culture, or when visiting the target culture act out according to the norms of that culture.

\section{Conclusion}

Cultural factors influence the development and use of language both in the acquisition stage and the practice stage (Alptekin \& Alptekin, 1984: 3). Therefore, applying sociopragmatics 
to the teaching of ESL/EFL plays a crucial role in language teaching, since it enables the learner learn the target language accurately and communicate appropriately. In other words, a learner must acquire linguistic, social, and pragmatic knowledge to communicate effectively in the target language. It is important for the EFL learner to gain to ability to understand underlying messages, implicatures and deeply rooted values of the target speech community; for, only then, s/he can avoid miscommunication and embarrassing situations, since it is the sociopragmatic competence which makes the speaker polite or rude in interactions.

The aim of foreign language teacher is to teach the target language so properly that the learner acquires communicative competence, pragmatic competence, as well as sociopragmatic competence to avoid breakdowns in communication. That is, s/he must not only focus on pragmalinguistic factors that lead to failure in learning a foreign language, but also to cultural assumptions and values, cultural behaviors, such as kinesics and proxemics including norms, rules and manners that lead to failure in learning the language.

If the teacher is a non-native speaker of the target language, he himself/herself has to learn the above mentioned sociopragmatic elements properly in order to teach them accurately to hinder misunderstanding when coming across different uses of those elements. For instance, the English gesture cross-fingers which illustrates the idiom keep your fingers crossed to wish good luck, might be misinterpreted by Turkish students, and lead to miscommunication (Curry, 1986:58). In Turkish context, especially with children, it means, one is cross with you and does not want to talk to you anymore. Therefore, for Turkish students it might cause failure in English if s/he is not taught the cultural meaning of this gesture. Otherwise, $\mathrm{h} /$ she will misinterpret it and think that the person using this gesture does not want to talk to him/her anymore, which can be regarded as an error caused by negative transfer from native culture.

The teacher can provide the students with verbal and non-verbal sociopragmatic elements leading to failure from authentic materials, such as newspapers, magazines, novels, songs, movies, and the like. Students seeing the proverbs, idioms, slang, folklore, superstitions, gestures, and facial expressions in context can better learn the target culture and interpret different norms properly. They can avoid misusing those when interacting with native speakers of the target language by practicing them in native-like situations in the classroom with appropriate methodologies related to the needs of the students, created by the teacher. Consequently, the more the learners are exposed to cultural elements of the target language, the more they become able to express themselves in that language effectively and gain mutual intelligibility.

To conclude, as Chandler (2002) explains, according to the Saphir-Whorf hypothesis (Whorfianism), the world view of an individual is determined by the language s/he speaks. 
Hence, in learning a foreign language $s$ /he has to recognize and understand a different world view, the one of the target language, by adapting a positive and open-minded attitude toward cultural differences, particularly the ones between the native and the target language. That is, cultural differences might lead to misunderstanding when people from different cultures interact. The polite thing would be to not apply the same politeness assumptions to people who come from a different culture. So, it is better if the teacher is aware of these differences, is cautious to sociopragmatic failure made by his/her students, and strives to teach them the accurate forms of those failures, with the aid of semiotic approaches and the communicative method, or methods tailored for the specific needs of the students. All these efforts will lead to fluent and competent communication in the target language and adjust ones achievement in sociopragmatic competence.

\section{References}

Alptekin, C. and M. Alptekin. (1984). The question of culture: EFL teaching in non-English speaking countries. ELT Journal, 38, (1), 3-10.

Anmer, C. (1992). The Methuen dictionary of clichés. London, Michelin House.

Birdwhistell, R. (1970). Kinesics and context: Essays on Body Motion Communication. University of Pennsylvania, Penn Press.

Chandler, D. (2002). The Sapir-Whorf Hypothesis. Retrieved 12 January 2016, from http://www. aber.ac.uk/media/Documents/short/whorf.html

Cotton, G. (2013). Gestures to Avoid in Cross-Cultural Business: In Other Words, 'Keep Your Fingers to Yourself!' The Huffington Post. Retrieved 22 December 2015 from http://www. huffingtonpost.com/gayle-cotton/cross-cultural-gestures_b_3437653.html

Crystal, D. (1987). The Cambridge Encyclopedia of language. Cambridge, CUP.

Curry, D. (1986). Illustrated American idioms. Office of English Language Programs. Materials Branch. Washington, D.C.

Dunkling, L. (1993). The Guinness book of curious phrases. London, Guinness Publishing

Ellis (1986). Understanding second language acquisition. Oxford, OUP.

Hall, E. T. (1966). The hidden dimensions. Garden City, New York, Doubleday.

Holmes, J. (1992). An introduction to sociolinguistics. London, Longman.

Kramsch, C. (1994). Culture in Language Teaching. Oxford, OUP.

Leech, G.N. (1983). Principles of pragmatics: an introduction. London, Longman.

Martin, G. (2016). English proverbs. Retrieved 15 August 2016, from http://www.phrases.org.uk/ meanings/proverbs.html

Matthews, P. (2007). Concise Oxford dictionary of linguistics. Oxford, OUP 
Microsoft Encarta (2000). Folklore. CD-ROM. Redmond, Microsoft.

Microsoft Encarta (2000). Superstitions. CD-ROM. Redmond, Microsoft.

Nordquist, R. (2016). About Education. Retrieved in January 2016, from http://grammar.about. $\mathrm{com} / \mathrm{od} / \mathrm{mo} / \mathrm{g} /$ Nonverbal-Communication.htm

Politzer, R. (1959). Developing cultural understanding through foreign language study. In report of the fifth annual round table meeting on linguistics and language teaching, Washington, DC Georgetown University Press, pp. 99-105.

Sinclair, J. (1994). Collins COBUILD Advanced Learner's English Dictionary. Glasgow, Harper Collins Publishers.

Smith, L. E. (1987). Discourse across cultures: Strategies in world Englishes. New York, Prentice Hall.

Soars, L. and J. Soars (1998). New Headway Upper-Intermediate English Course. Oxford, Oxford University Press.

Stern, K. (1998). Longman idioms dictionary. Harlow, Longman.

Vargas, M. (1986). Louder than words. Ames, Iowa State University Press.

Wolfson, N. (1989). Perspectives: Sociolinguistics and TESOL. New York, Newbury House. 
